\title{
MINIREVIEW
}

\section{Possible role of different animal species in maintenance and spread of murine gammaherpesvirus 68 in the nature}

\author{
M. WÁGNEROVÁ ${ }^{1}$, A. CHALUPKOVÁ ${ }^{1}$, Z. HRABOVSKÁ ${ }^{1}$, L. ANČICOVÁ ${ }^{1}$, J. MISTRÍKOVÁ ${ }^{1,2^{*}}$ \\ ${ }^{1}$ Department of Microbiology and Virology, Faculty of Natural Sciences, Comenius University, Bratislava, Slovak Republic; ${ }^{2}$ Institute \\ of Virology, Slovak Academy of Sciences, Dúbravská cesta 9, 84505 Bratislava, Slovak Republic
}

Received July 15, 2014; accepted February 9, 2015

\begin{abstract}
Summary. - Murine gammaherpesvirus 68 (MHV-68), isolated from a bank vole (Clethrionomys glareolus) in Slovakia in 1976 is a natural pathogen of wild murid rodents. This review is focused to biological properties of this pathogen, the mode of its maintenance in murid rodents as reservoir animals, mechanisms of its spread to other animals in the same biotope as well as to livestock and household animals. Potential role of ticks as vectors and the possibility of infection of humans with this virus are considered as well. All the above evidence of the virus infection of various hosts is based on serological or molecular analytical data. The presented knowledge indicates important epizootologic consequences, namely harboring and permanent maintenance of the virus in murid rodents as reservoir animals with a real possibility of spread to other animals in the same biotope. These relationships imply a cross-species virus transmission with potential serious consequences for the infected animals or humans.
\end{abstract}

Keywords: murine gammaherpesvirus 68; murid rodents; reservoir aimals; humans; spread; epidemiology

\section{Contents:}

1. Introduction

2. The virus

3. Maintenance of the virus in reservoir animals

4. Spread of the virus to other animal species

5. Infection of humans with the virus

6. Conclusions

*Corresponding author. E-mail: virumis@savba.sk; phone: +4212-59302426, +421-2-547731172.

Abberviations: $\mathrm{BRHV}=$ Brest herpesvirus; $\mathrm{EBV}=$ Epstein-Barr virus; HVS = herpesvirus saimiri; KSHV = Kaposi's sarcomaassociated herpesvisrus; LCMV = lymphocytic choriomeningitis virus; MHV-68 = murine gammaherpesvirus 68; VNT = virus neutralization test; $\mathrm{WMHV}=$ wood mouse herpesvirus

\section{Introduction}

The role of individual animal species in emerging viral diseases is not known. It is generally accepted that in case viruses exhibit host-switching, its results may be catastrophic, namely disease and death of animals and humans. Zoonotic outbreaks reflect several factors including increased mobility of human population and demographic and environmental changes caused by globalization. The threat of emerging viruses and the fact that there are no vaccines against the most common viral zoonoses drive research in this field. Transmission of a virus from its natural to other host species with serious outcome may be well documented on the example of herpesvirus saimiri which is not harmful to its natural host, Old world monkey but is even lethal to humans (Blaškovič et al., 1987). Another example can be the pseudorabies virus (Aujeszky's disease virus), non-pathogenic 
to pig as reservoir animal but lethal to cattle, deer, pet cats and dogs (Sabó, 1981).

In discussing herpesviruses it should be noted that they represent a spectacular evolutionary success as they have been found in all vertebrates and each of them is associated with a single host species. The host specificity of herpesviruses indicates that they have evolved together with their hosts over long time periods and have adapted to them. Herpesviruses exhibiting high patogenicity for humans or farmed animals are invariably the result of disequilibrium promoted by human activity (Davison, 2002). The number of newly identified herpesviruses constantly increases so that at present the total of all herpesviruses exceeded twohundreds. Only eight of these infect humans and cause different diseases (Wágnerová a Mistríková, 2011). This trend implies permanent demands on taxonomic classification of herpesviruses. In this context the former family Herpesviridae was recently uptated to a new order, Herpesvirales consisting now from 3 families, 3 subfamilies, 17 genera and 90 species (Davison, 2010).

One of relatively novel herpesviruses is also the murine gammaherpesvirus 68 (MHV-68) which was isolated from wild murid rodents in Slovakia (Blaškovič et al., 1980) and later in other European countries including UK (Blasdel et al., 2003; Telfer et al., 2007). The objective of this review was to cover the biology of MHV-68 and the role of individual animal hosts species in its maintenance and spread in the nature. Despite herpesviruses represent one of the most intensively studied group of viruses, many aspects of their epidemiology and ecology remain still unknown.

\section{The virus}

In designating the reviewed virus the most frequently used common name "murine gammaherpesvirus 68" (MHV-68) in preference to formal taxonomic name "murid herpesvirus 4" and to another less frequent common name "mouse herpesvirus strain 68" was chosen.

MHV-68 was originally isolated from wild murid rodents in Slovakia in 1976 as their natural pathogen (Blaškovič et al., 1980). At the same time some more murine herpesviruses, namely MHV-60 and MHV-72 were isolated from bank vole (Clethrinomys glareolus) and MHV-76 and MHV-78 from yellow-necked mouse (Apodemus flavicollis), all in Slovakia. Later on, further isolates followed: MHV-Šumava from $A$. flavicollis in Bohemia (Mistríková and Blaškovič , 1985) and MHV-4556 and MHV-5682 from the same host in Slovakia (Kožuch et al., 1993). Based on biological properties, MHV-68 was first taken for an alphaherpesvirus (Svobodová et al., 1987), however, later molecular studies including sequencing of the genome indicated that it is a gammaherpesvirus, a member of the subfamily Gammaherpesvirinae
(Virgin et al., 1997). A definitive acceptance of MHV-68 as gammaherpesvirus was effected in 1995 by its classification as "murid herpesvirus 4" to a new species, Murid herpesvirus 4 in the genus Rhadinovirus, the subfamily Gammaherpesvirinae with synonymic common names "murine gammaherpesvirus 68" and "mouse herpesvirus strain 68" (Murphy et al., 1995). The other murine herpesvirus isolates mentioned above, namely MHV-60, MHV-72, MHV-76, MHV-78, MHV-Šumava, MHV4556, and MHV-5682 remained so far unclassified and are tentatively considered as gammaherpesviruses.

In 2010, two more gammaherpesviruses were isolated; one from field vole (Microtus agrestis) and the other from wood mouse (Apodemus sylvaticus). The genome of the latter, designated wood mouse herpesvirus (WMHV) was completely sequenced and showed an $85 \%$ nucleotide sequence identity with that of MHV-68. Another gammaherpesvirus named Brest herpesvirus (BRHV), isolated from a whitetoothed shrew (Crocidura russula) was partially sequenced and gave a $99.25 \%$ identity with WMHV. Also the pathogenesis of WMHV in wood mice was very similar to that of MHV-68 (Hughes et al., 2010). Thus WMHV and BRHV were considered strains of a new virus species.

To cover basic molecular biological characterirstics of MHV-68 it is a DNA virus with double-stranded genome of $\sim 118 \mathrm{kbp}$ that encodes at least 80 genes and corresponding number of proteins. Based on genome sequences MHV68 is similar to gammaherpesviruses herpesvirus saimiri (HVS), Kaposi's sarcoma-associated herpesvirus (KSHV) and Epstein-Barr virus (EBV).

The importance of MHV-68 resides in its worldwide use as an experimental model for studying a gammaherpesvirus infection. Gammaherpesviruses are considered archetypal pathogenic persistent viruses. The known human gamaherpesviruses, EBV and KSHV are host-specific and lack a convenient in vivo model. This makes the related animal gammaherpesviruses an important source of information. In particular a laboratory mouse infected with MHV-68 is commonly used as a general model of gammaherpesvirus pathogenesis and a tool in the development of therapeutic strategies against these viruses.

\section{Maintenance of the virus in reservoir animals}

The natural reservoir is an epidemiological term designating natural resource and environment for the persistence of the virus and the disease that occurs among the non-reservoir animals and humans rarely in the form of epidemics and is not present in their population between epidemics. Wild murid rodents represent the reservoir for MHV-68, hantaviruses, tick born encephalitis virus, and lymphocytic choriomeningitis virus (LCMV) (Grešíková et al., 1986; Bardoš, 1965; Lee et al., 1981). Rodents were confirmed as important reservoir 
Table 1. Prevalence of serum antibodies to MHV-68 in various hosts

\begin{tabular}{|c|c|c|c|}
\hline & Host & $\begin{array}{l}\text { Positivity for serum } \\
\text { antibodies }(\%)\end{array}$ & References \\
\hline \multirow{4}{*}{$\begin{array}{l}\text { Reservoir animals: wood } \\
\text { mouse, bank vole, field } \\
\text { vole, yellow-necked } \\
\text { mouse, wild mouse }\end{array}$} & A. flavicollis & $0-12.5$ & Mistríková and Blaškovič, 1985 \\
\hline & A. agrarius, A. sylvaticus, $M$. arvalis & 20.7 & Telfer et al., 2007 \\
\hline & $\begin{array}{l}\text { A. flavicollis, A. sylvaticus, M. arvalis, } \\
\text { C. glareolus }\end{array}$ & $30-40$ & Mistríková and Blaškovič, 1985 \\
\hline & A. flavicollis, C. glareolus, M. arvalis & 31.4 & Klempa et al., 2001 \\
\hline \multirow{6}{*}{$\begin{array}{l}\text { Non-reservoir } \\
\text { wild animals }\end{array}$} & Wild boar (Sus Scrofa) & 7.7 & Špajdelová and Sabó, 2009 \\
\hline & Red fox (Vulpes Vulpes) & 16.7 & Hamzová et al., 2005 \\
\hline & Fallow deer (Dama Dama) & 18.2 & Špajdelová and Sabó, 2009 \\
\hline & Red deer (Cervus Elephus) & 50 & Špajdelová and Sabó, 2009 \\
\hline & European roe deer (Capreolus Capreolus) & 12.5 & Špajdelová and Sabó, 2009 \\
\hline & Hare (Lepus Europeus) & 24.4 & Špajdelová and Sabó, 2009 \\
\hline \multirow{6}{*}{$\begin{array}{l}\text { Farm, domestic and } \\
\text { household animals }\end{array}$} & Domestic goat (Capra hircus) & 15 & Špajdelová, 2009 \\
\hline & Horse (Equus Caballus) & 6 & Špajdelová, 2009 \\
\hline & Cattle (Bos Primigenius) & 8.7 & Špajdelová, 2009 \\
\hline & Domestic dog (Canis lupus familiaris) & 17.1 & Špajdelová and Grmanová, 2010 \\
\hline & Domestic cat (Felis silvestris catus) & 12.2 & Špajdelová and Grmanová, 2010 \\
\hline & Wild house mouse (Mus dommesticus) & $3-13$ & Becker et al., 2007 \\
\hline Vector? & Tick (Ixodes Ricinus)* & 1.8 & Ficová et al., 2011 \\
\hline \multirow{5}{*}{ Humans } & Laboratory personnel working with the virus & $\begin{array}{c}35 \text { ( ELISA) } \\
40 \text { (VNT) }\end{array}$ & Mistríková et al., 2000 \\
\hline & Hunters & 11.1 & Hamzová, 2005 \\
\hline & People coming into contact with forest animals & 12.5 & Špajdelová and Sabó, 2009 \\
\hline & Patients from infectious wards & 5 & Marková et al., 2007 \\
\hline & Patients with various diagnoses & 16 & Mistríková et al., 2000 \\
\hline
\end{tabular}

Antibodies assayed by VNT, complement-fixation test or ELISA. "MHV-68 positivity by PCR detection.

of 11 viral, bacterial, and parasitic agents including three different hantaviruses, LCMV, orthopoxvirus, Leptospira spp., Borrelia spp., Rickettsia spp., Bartonella spp., Coxiella burnetii, and Toxoplasma gondii in Austria (Schmidt et al., 2014). The pathogenesis of MHV-68 infection in wild murid rodents has been well documented by detection of the virus in various organs and by assay of specific serum antibodies. In this context Klempa et al. (2001) detected the virus by PCR in the blood of C. glareolus and A. flavicollis in Slovakia in $31.4 \%$. An analysis of 381 sera from A. flavicollis, C. glareolus, M. arvalis and M. musculus in former Czechoslovakia for specific antibodies by a complement-fixation test revealed $0-12.5 \%$ positivity and titers of 8 -16 in dependence on the host and locality (Mistríková and Blaškovič, 1985). A more extensive study on 935 sera from 9 different host species showed that specific antibodies in titers of 2-256 were present in A. flavicollis and C. glareolus from all localities, while those in A. sylvaticus, M. arvalis and M. agrestis were less frequent (Blaškovič et al., 1987).

In studying the incidence of the virus infection in free-living rodents in UK Blasdel et al. (2003) found its endemicity in $A$. sylvaticus but not in C. glareolus and $M$. agrestis, based on seropositivities of $13-22 \%, 2,7 \%$ and $0 \%$, respectively. Viral DNA was detected by PCR in the lungs and less commonly in the spleen of these animals. Another study of specific antibodies in C. glareolus and A. sylvaticus in UK revealed their higher prevalence in the latter host (Telfer et al. (2007), thereby supporting a generally accepted view that even though MHV-68 was originally isolated from C. glareolus, its major natural host is A. sylvaticus. A two-year study of the epidemiology of the virus infection in $A$. sylvaticus and C. glareolus by Knowles et al. (2012) suggested that (i) male reproductive behaviours of these animals represnt an important natural route of transmission of this virus and (ii) this infection may have a detrimental effect on other wild hosts, thus objecting the view that gammaherpesviruses have limited impacts on natural co-evolved host species.

As for the prevalence of the virus infection in wild house rodents, an investigation on Mus domesticus in UK using serology showed values of 3-13\% (Becker et al., 2007).

In experimental studies of pathogenesis of MHV-68 mostly laboratory mice are employed as model hosts. A comparative study of the virus infection in its natural host, bank vole and laboratory mouse by luciferase imaging and classical virological methods showed that the virus replicated in bank vole approximately 1000 -fold less effectively than in mouse (Francois et al., 2010). 
In considering the transmission of the virus two basic routes are evaluated: horizontal (between individual animals) or vertical (between mother and fetus or newborn) via placenta or breast milk.

In a study on pregnant Balb/c mice chronically infected with the virus, Štiglincová et al. (2011) found the virus in breast milk, tumors in mothers, premature termination of pregnancy and reduced number and size of newborns. All these results indicated vertical transmission of the virus and its teratogenicity. Hricová and Mistríková (2008) detected the virus in lactic glands and brest milk of infected mice already on day 4 , in urine and salivary glands on day 9 and in saliva and tear glands on day 14 post infection. These results indicated that intranasal and peroral routes of infection are most probably involved in the virus contraction.

In summary, in considering the maintenance of MHV-68 in reservoir animals the possible way of infection at early age, from infected mother to fetus or newborn is via placenta or breast milk. In adulthood, the transmission is horizontal via air, saliva or urine. There is a real possibility that the virus is transmitted not only to the reservoir animals representing various phylogenetically distant rodents but also to other animal species inhabitating the same biotope. The hypotheses about the likely routes of dissemination of the virus were experimentally confirmed. Thus the respiratory tract apeears the main gateway for this virus, i.e. its natural dissemination is carried out by air. After an acute phase of infection that is usually inapparent there follows a chronic phase with lifelong latency and possible reactivation of latent virus. During the infection the virus is excreted via the respiratory tract, saliva, tears, and urine (Hricová and Mistríková, 2008).

\section{Spread of the virus to other animal species}

With regard to the fact that MHV-68 is capable of infecting different phylogeneticaly distant species of murid rodents such as C. glareolus (the subfamily Microtinae) and A. flavicollis (the subfamily Murinae) it can be hypothesized that this virus could theoretically overstep the species specificity more extensively. This assumption was confirmed by examining the sera of non-reservoir animals occupying a common space with murid rodents.

Thus virus-neutralizing antibodies were detected in sera of wild animals such as fallow deer, red deer, European roe deer, wild boars, daniels, pheasants, mouflons, foxes and hares from different areas in Slovakia (Mistríková et al., 2000; Hamzová et al., 2005; Špajdelová and Sabó, 2009). The detection positivity was partial and varied in dependence on host, place and time (Table 1).

Studies on domestic and farm animals such as horses, cattle, goats, cats and dogs in Slovakia gave similar results (Špajdelová, 2009; Špajdelová and Grmanová, 2010) (Table 1).
A sort of surprise was the finding of the virus in Ixodes ricinus (Ficová et al., 2011) that implies the possible involvement of this vector in the spread of the virus in wild mouse in nature. This finding was confirmed experimentally by infected ticks naturally infected with murine herpesvirus sucking on experimentally infected mice. The virus survived metamorphosis ticks, and other developmental stage ticks were transferred to a clean laboratory mice. Murine virus was demonstrated in the salivary glands of ticks which is consistent with biological transmission by saliva of ticks.

Virus survived in ticks without loss of infectivity at least 4 months as demonstrated ability of the virus to multiply in mammalian cells and form plaques. Unlike most pathogenic arboviruses are able to influence MHV-68 infection to ticks, which led to their reduced ability metamorphosis compared with uninfected ticks. This was the first experimental evidence that the herpes virus can be transmitted by blood of suckling arthropod (V. Hajnická, personal communication).

\section{Infection of humans with the virus}

There is no evidence on the virus infection of humans or on studies on the virus pathogenicity for humans (Mistríková et al., 2000). All the relevant information concerns virus-specific serum antibodies in the persons more or less exposed to the virus. Thus such antibodies were found by ELISA in some percentage in laboratory pesonnel long time directly working with the virus, hunters coming into contact with the virus indirectly in the wild and even in persons without any real contact to the virus such as patients with various infection or non-infection diagnoses (Mistríková et al., 2000, 2006; Hamzová et al., 2005; Špajdelová and Sabó, 2009; Marková et al., 2007) (Table 1). The only entirely negative group was blood donors from transfusion stations (Mistríková et al., 2006). In view of a relatively high prevalence of antibodies (16\%) in the group of patients with various diagnoses we attempted to exclude possible false-positive results caused by crossreaction of the MHV-68 antigen with antibodies to other human herpesviruses, particularly HSV-1, HCMV and EBV in ELISA. The results obtained by VNT and immunofluorescence assay (IFA) proved a false positivity of the ELISA due to cross-reactivity of MHV-68 with EBV. In addition, a high prevalence of antibodies to EBV was demonstrated in general population (Mistríková et al., 2000; Stewart et al., 1994, 1999; Virgin et al., 1997; Efstathiou et al., 1990).

In the context of the issue of infection of humans with MHV-68 it could be of interest the finding of in vitro transformation of human cells with this virus (F. Golais, personal communication). 


\section{Conclusions}

Since we recently face a constant increase in the number of novel virus isolates or even viruses in general and herpesviruses in particular, we principally cannot exclude the emergence of novel viral pathogens of animals or humans. Prooving the presence of relatively novel herpesvirus, MHV-68 and/or its antibodies in various hosts enabled identification of its reservoir animals and understanding of mechanisms of its maintenance within the reservoir and spread to other wild, farm or household animals including humans. In general, the knowledge of biology, epidemiology and ecology of this virus can help us to prevent known virus infections and to avoid potential infections caused by so far unknown agents.

Acknowledgement. This work was supported by the grant VEGA 1/0617/15 from the Scientific Grant Agency of the Ministry of Education of Slovak Republic and Slovak Academy of Sciences.

\section{References}

Bárdoš V (1965): Ecology of arborviruses in Czechoslovakia. Publishing House of Slovak Academy of Sciences, p.188 (in Slovak).

Becker SD, Bennett M, Stewart JP, Hurst JL (2007): Serological survey of virus infection among wild house mice (Mus domesticus) in the UK. Lab. Anim. 41, 229-238. http:// dx.doi.org/10.1258/002367707780378203

Blasdell K, Mc Cracken C, Morris A, Nash AA, Begon M, Bennett M, Stewart JP (2003): The wood mouse is a natural host for murid herpesvirus 4. J. Gen. Virol. 84, 111-113. http:// dx.doi.org/10.1099/vir.0.18731-0

Blaškovič D, Stančeková M, Svobodová J, Mistríková J (1980): Isolation of five strains of herpesviruses from two species of free-living small rodents. Acta Virol. 24, 468.

Blaškovič D, Sékeyová Z, Kožuch O, Lysý J, Labuda M, Cupalová A, Mazák V, Vlček M, Chmela J, Hubálek Z, Jirková Z, Janáková K (1987): Serological evidence of distribution of herpesviruses in Czechoslovakia. Biológia 42, 1973-1082 (in Slovak).

Davison AJ (2002): Evolution of the herpesviruses. Vet. Microbiol. 86, 69-88. http://dx.doi.org/10.1016/S0378-1135(01)00492-8

Davison AJ (2010): Herpesvirus systematic. Vet. Microbiol. 143, 52-69. http://dx.doi.org/10.1016/j.vetmic.2010.02.014

Efstathiou S, Ho YM, Hall S, Styles CJ, Scott SD, Compels NA (1990): Murine herpesvirus type 68 is genetically related to the gammaherpesviruses Epstein-Barr virus and herpesvirus saimiri. J. Gen. Virol. 71, 1356-1372. http:// dx.doi.org/10.1099/0022-1317-71-6-1365

Fauquet CM, Mayo MA, Maniloff J, Desselberger U, Ball LA (Eds) (2005): Virus Taxonomy. Eighth Report of the International Committee on Taxonomy of Viruses. ElsevierAcademic Press, Amsterdam.
Ficová M, Betáková T, Pančík P, Václav R, Prokop P, Halásová Z, Kúdelová M (2011): Molecular Detection of murine herpesvirus 68 in ticks feeding on free-living reptiles. Microb. Ecol. 62, 862-867. http://dx.doi.org/10.1007/ s00248-011-9907-7

Francois S, Vidick S, Sarlet M, Michaux J, Koteja P, Desmecht D, Stewenson PG, Vanderplasschen A, Gillet L (2010): Comparative study of murid gammaherpesvirus 4 infection in mice and in a natural host, bank voles. J. Gen. Virol. 91, 2553-2653. http://dx.doi.org/10.1099/vir.0.023481-0

Grešíková M, Bilčíková M, Bilčík P (1986): Hemorrhagic fever with renal syndrome. Publishing House of Slovak Academy of Sciences, Bratislava, p.126 (in Slovak).

Hamzová S, Mikovičová A, Timková J, Sabó A (2005): Serological analysis of circulation of murine gammaherpesvirus in human population and chosen species of animals. Acta Chemother. 125-128 (in Slovak).

Hricová M (2004): Murine herpes virus shedding during experimental infection of laboratory mice. Comenius University, Bratislava, Ph.D. Thesis (in Slovak).

Hricová M, Mistríková J, (2007): Murine gammaherpesvirus 68 serum antibodies in general human population. Acta Virol. 51, 283-287.

Hricová M, Mistríková J (2008): Ecological characterization implications of the murine gammaherpesvirus 68 . Biológia 63, 753-755.

Hughes DJ, Kipar A, Milligan SG, Cunningham C, Sanders M, Quail MA, Rajandream MA, Efstathiou S, Bowden RJ, Chastel C, Bennet M, Sample JT, Barell B, Davison AJ, Stewart JP (2010): Characterization of a novel wood mouse virus related to murid herpesvirus 4. J. Gen. Virol. 91, 867-879. http://dx.doi.org/10.1099/vir.0.017327-0

Chmela J, Hubálek Z, Jirková Z, Janáková K (1987): Serological survey of distribution of herpesviruses in Czechoslovakia. A laboratory analysis. Biológia 42, 1073-1082 (in Slovak).

Klempa B, Mačáková K, Labuda M, Kúdelová M (2001): Detection of murine herpesvirus (MHV) among free-living rodents by nested PCR. Infect. Dis. Rev. 3, 31-33.

Knowles SCL, Fenton A, Pedersen B (2012): Epidemiology and fitness of wood mouse herpesvirus in a natural host population. J. Gen. Virol. 93, 2447-2456. http://dx.doi. org/10.1099/vir.0.044826-0

Kožuch O, Reichel M, Leššo J, Remeňová A, Labuda M, Lysý J, Mistríková J (1993): Further isolation of murine herpesvirus from small mammals in southwestern Slovakia. Acta Virol. 37, 101-105.

Lee PW, Amyx HL, Gibbs CJ, Gajdusek DC, Lee HW (1981): Propagation of Korean hemorrhagic fever virus in laboratory rats. Infect. Immun. 31, 334-338.

Marková G, Majerníková M, Špajdelová J (2007): Incidence of antibodies to murine gammaherpesvirus MHV-68 in some animall species and humans. Proceedings of Students' Research Conference, Biological and Environmental Section, pp. 8-10 (in Slovak).

Mistríková J, Blaškovič D (1985): Ecology of the murine alphaherpesvirus and its isolation from lungs of rodents in cell culture. Acta Virol. 29, 312-317. 
Mistríková J, Remeňová A, Leššo J, Stančeková M (1994): Replication and persistence of murine herpesvirus 72 in lymphatic system and peripheral blood mononuclear cells of BALB/c mice. Acta Virol. 38, 151-156.

Mistríková J, Kožuch O, Klempa B, Kontseková E, Labuda M, Mrmusová M (2000): New knowledge about the ecology and epidemiology of murine herpesvirus isolated in Slovakia. Bratisl. Lek. Listy 101, 157-162 (in Slovak).

Mistríková J, Hricová M, Šupolíková M (2006): Contribution to the problem of infection of humans with a murine gammaherpesvirus. Acta Virol. 50, 71-72.

Mistríková J, Sokolová J, Chalupková A, Hrabovská Z, Jarčušková J, Wágnerová M (2013): Overview of geographic distribution of murine herpesvirus (MuHV-4) in Slovakia. Geographical overview of incidence of murid herpesvirus 4 (MuHV 4) in Slovakia. Proceedings of the Students' Research Conference Labuda Days III, Bratislava, pp. 59-62 (in Slovak).

Murphy FA, Fauquet CM, Bishop DHL (1995): Virus Taxonomy. Classification and Nomenclature of Viruses. Sixth Report of the International Committee on Taxonomy of Viruses. Arch. Virol. 10, 586.

Nash A, Dutia B, Stewart J, Davison AJ (2001): Natural history of murine gammaherpesvirus infection. Philos. Trans. R. Soc. Lond. B Biol. Sci. 365, 569-579. http://dx.doi. org/10.1098/rstb.2000.0779

Rašlová H, Berebbi M, Rajčáni J, Sarasin A, Matis J, Kúdelová M (2001): Susceptibility of mouse mammary glands to murine gammaherpesvirus 72 (MHV-72) infection: Evidence of MHV-72 transmission via breast milk. Microb. Pathogen. 31, 47-58. http://dx.doi.org/10.1006/ mpat.2001.0441

Sabó A (1981): Aujeszky disease. Publishing House of Slovak Academy of Sciences, p. 269 (in Slovak).

Schmidt S, Essbauer S, Mayer-Scholl A, Poppert S, Schmidt-Chanasit J, Klempa B, Henning K, Schares G, Groschup MH, Spitzenberger F, Richter D, Heckel G, Ulrich RG (2014): Multiple infections of rodents with zoonotic pathogens in Austria. Vect. Zoon. Dis. 14, 467-475. http://dx.doi. org/10.1089/vbz.2013.1504

Sokolová J (2011): Extension of current knowledge of ecology of murine herpesviruses by identification of new animal species as hosts. Diploma Thesis, Faculty of Natural Sciences, Bratislava (in Slovak).

Stewart JP, Janjua NJ, Sunil-Chandra NP, Nash AA, Arrand JR (1994): Characterization of murine gammaherpesvirus glycoprotein B (gB) homolog : similarity to Epstein-Barr Virus B (gp 110). J. Virol. 68, 6496-6504.

Stewart JP, Micali N, Usherwood EJ, Bonina L, Nash AA (1999): Murine gammaherpesvirus 68 glycoprotein 150 protects against virus-induced mononucleosis: a model system for gammaherpesvirus vaccination. Vaccine 17, 152-157. http://dx.doi.org/10.1016/S0264-410X(98)00190-X

Svobodová J, Blaškovič D, Mistríková J (1982): Growth characteristics of herpesviruses isolated from free-living small rodents. Acta Virol. 26, 256-263.

Svobodová J, Blaškovič D, Rajčáni J, Leššo J (1987): Murine herpesviruses, their experimental pathogenesis and ecological importance. Bratisl. Lek. Listy, 87, 649-658 (in Slovak).

Špajdelová J (2009): Study of MHV 68 in domestic animals Eguus caballus, Bos primigenius F. taurus and Capra hircus. Proceedings of Young Researchers' Conference, Brno, pp. 100-102 (in Czech).

Špajdelová J, Sabó A (2009): Circulation of HMHV-68 in wildlife and humans in contact with them. In: Garaj P: Hunters' management and wildlife protection. Technical University, Zvolen, pp. 147-150.

Špajdelová J, Grmanová L' (2010):) : MHV-68 in pet dogs and cats. Slovenský veterinársky časopis 35, 97-99 (in Slovak).

Štiglincová V, Chalupková A, Hrabovská Z, Čipková J, Wágnerová M, Mistríková J (2011): Vertical transmission of murine gammaherpesvirus 68 in mice. Acta Virol. 55, 55-59. http://dx.doi.org/10.4149/av 20110155

Telfer S, Bennett M, Carslake D, Helyar S, Begon M (2007): The dynamics of murid gammaherpesvirus 4 within wild, sympatric populations of bank voles and wood mice. J. Wildlife Dis. 43, 32-39. http://dx.doi.org/10.7589/0090-3558-43.1.32

Virgin HWIV, Latreille P, Wamsley P, Hallsworth K, Weck KE, Dal Canto AJ, Speck, SH (1997): Complete sequence and genomic analysis of murine gammaherpesvirus 68 . J. Virol. 71, 5894-5904.

Wágnerová M, Mistríková J (2011): Overview of herpesviruses of humans and other animal species. Slovenský lekár No. 5, pp. 10-20 (in Slovak). 